\title{
Preharvest Foliar Sprays of Prohexadione-calcium, a Gibberellin- biosynthesis Inhibitor, Induce Chlorophyll Degradation and Carotenoid Synthesis in Citrus Rinds
}

\author{
Graham H. Barry ${ }^{1,2}$ \\ Citrus Research International, Department of Horticultural Science, \\ Stellenbosch University, P. Bag X01, Matieland 7602, Stellenbosch, South \\ Africa \\ Smit le Roux \\ Department of Horticultural Science, Stellenbosch University, P. Bag X01, \\ Matieland 7602, Stellenbosch, South Africa
}

Additional index words. carotenoid-to-chlorophyll ratio, growth retardants, Regalis ${ }^{\circledR}$, rind color, vegetative vigor

\begin{abstract}
Rind color is an important cosmetic preference of consumers when purchasing citrus fruit. As citrus fruit mature, a decrease in chlorophyll concentration unmasks the presence of carotenoid pigments followed by further synthesis of carotenoids, resulting in the first appearance of the characteristic orange color of mandarins and sweet oranges. Factors contributing to invigorating growing conditions are antagonistic to optimal rind color development and tree vegetative vigor as well as high gibberellin and cytokinin levels are also thought to adversely affect rind color. Thus, a method to increase preharvest rind color by moderating vegetative vigor using a growth retardant was investigated. Prohexadione-calcium (ProCa; Regalis ${ }^{\circledR}$ ), a gibberellin-biosynthesis inhibitor with growth retardant activity, was applied to 'Nules Clementine' mandarin (Citrus reticulata Blanco), 'Navelina Navel' orange $[C$. sinensis (L.) Osbeck], and 'Eureka' lemon [C. limon (L.) Burm. f.] during the 2005 and 2006 seasons at 200 and $400 \mathrm{mg} \cdot \mathrm{L}^{-1}$ a.i. Rind color rating, colorimeter measurements, and pigment analyses were conducted directly after harvest, after ethylene degreening, and 3 weeks after cold storage. In the 2005 season, ProCa significantly increased rind color of 'Nules Clementine' mandarin and 'Navelina Navel' orange directly after harvest and after ethylene degreening by decreasing chlorophyll and increasing carotenoid concentrations in the flavedo of fruit but did not affect the pigment concentration of 'Eureka' lemon despite an improvement in rind color rating. After cold storage, however, rind color was not significantly different among treatments. In the 2006 season, rind color was significantly increased directly after harvest, and chlorophyll degradation together with carotenoid synthesis of all Citrus spp. tested were stimulated by the late $400 \mathrm{mg} \cdot \mathrm{L}^{-1}$ ProCa application. Therefore, foliar spray application of ProCa at a concentration of 400 $\mathrm{mg} \cdot \mathrm{L}^{-1}$ applied 6 plus 3 weeks before anticipated harvest has the potential to increase preharvest rind color of early-maturing citrus cultivars as a result of increased carotenoid-to-chlorophyll ratio. This treatment provides a novel approach to manipulate chlorophyll degradation and carotenoid synthesis in citrus fruit, and these results support the hypothesis that there may be an inverse relationship between vegetative vigor and rind color development of citrus fruit. Therefore, by moderating vegetative vigor through the use of growth retardants, rind color of citrus fruit can be enhanced.
\end{abstract}

Rind color of citrus fruit is an important cosmetic preference of consumers when purchasing citrus fruit who generally prefer a deep orange rind color (Krajewski, 1997). As citrus fruit mature, changes in rind color are the result of decreased chlorophyll and increased carotenoid concentrations in the flavedo of the rind (Eilati et al., 1969; Goldschmidt, 1988). These changes in rind pigments are mainly the result of the senescence of chlorophyllous tissue in the flavedo and result in the transformation of chloroplasts into chromoplasts (Camara and Brangeon, 1981; El-Zeftawi and Garrett, 1978; Mayfield and Huff, 1986; Thomson, 1966). Chloro-chromoplast transformation is an important metabolic event at fruit maturity resulting in "color break" of the rind and is affected by genetic, environmental, nutritional, and hormonal factors (Goldschmidt, 1988). "Color break," a colloquial term generally used in the citrus industries of the world, occurs when a decrease in chlorophyll concentration unmasks the presence of carotenoid pigments followed by further synthesis of carotenoids, resulting in the first appearance of the characteristic orange color of mandarins and sweet oranges (ElZeftawi, 1978; Goldschmidt, 1988; Jackson and Davies, 1999).

Citrus rind color is primarily a genetic trait and is secondarily affected by climatic and other growing conditions that have a large influence on rind color when combined. The major factors affecting rind color are temperature (Young and Erickson, 1961), light (Sites and Reitz, 1949), nutrition (Reitz and Koo, 1960), plant water relations (Peng and Rabe, 1996), rootstock (Rabe and Von Broembsen, 1995), and phytohormones (Garcia-Luis et al., 1986). Other important factors include tree age, soil conditions, and crop load. Besides the direct effects of some of these factors on rind color, various indirect effects may also be important to rind color development. Furthermore, the interaction of seemingly minor factors may hinder rind color development.

Goldschmidt (1988) hypothesized that factors contributing to invigorating growing conditions are antagonistic to optimal rind color development. For example, young trees are more vigorous than older, mature trees (Krajewski, 1997). This vigor difference may be a major reason why fruit borne on young trees have inferior rind color compared with fruit borne on mature trees. Color development is also adversely affected by growth flushes during Stage III of fruit development caused by high fall temperatures or summer pruning. Such flushes are more common in trees bearing a low crop and in young trees of vigorous rootstock/scion combinations (Krajewski, 1997; Saunt, 2000). Rootstock vigor affects rind color development of the fruit of scions budded onto the rootstock. For example, fruit from scions budded on rough lemon (C. jambhiri Lush.) rootstock had medium-late color development, whereas 'Troyer' citrange [Poncirus trifoliata (L.) Raf. $\times C$. sinensis (L.) Osbeck] rootstock resulted in 8 to $10 \mathrm{~d}$ earlier rind color development, and scions on 'Swingle' citrumelo $[P$. trifoliata $($ L.) Raf. $\times C$. paradisi Macf.] had delayed rind color development (Rabe and Von Broembsen, 1995). Young, vigorously growing roots, beside other organs, are a major site for the biosynthesis of gibberellins and cytokinins, which are antagonistic to rind color development and are subsequently transported to the aerial portion of the tree through the xylem (Saidha et al., 1983). Vigorous rootstocks also have a higher hydraulic conductivity, allowing more water and mineral nutrients, e.g., nitrogen $(\mathrm{N})$, to be transported to leaves and fruit (Syvertsen, 1981). Peng and Rabe (1996) found that when deficit irrigation caused the soil water tension to reach $-70 \mathrm{kPa}$, better-colored fruit were obtained compared with normal irrigation with a soil water tension of $-30 \mathrm{kPa}$. The fruit harvested was better colored as a result of lower chlorophyll levels. Koo (1988) established that excess $\mathrm{N}$ (greater than 160 $\mathrm{kg} \cdot \mathrm{ha}^{-1} /$ year) increased the amount of green fruit (from $18 \%$ to $32 \%$ ) when the fruit were physiologically mature and ready for harvest.

Vegetative growth of citrus trees is stimulated by various environmental factors and 
nutrients, namely high temperature, high light intensity, N, and water (Syvertsen, 1981), as well as endogenous hormones, namely gibberellins and cytokinins (Coggins and Lewis, 1962; Saidha et al., 1983). Young leaves and fruit are major sites of gibberellin biosynthesis (Salisbury and Ross, 1992; Spiegel-Roy and Goldschmidt, 1996). High endogenous gibberellin concentrations enhance stem elongation (Mudzunga, 2000; Salisbury and Ross, 1992) and delay rind color development of citrus fruit (Garcia-Luis et al., 1985).

Goldschmidt (1988) showed that high gibberellin levels in fruit during maturation delayed chloroplast to chromoplast transformation and Gilfillan et al. (1974) showed that when $\mathrm{GA}_{3}$ was applied at color break, it resulted in unacceptably green fruit at harvest. Gibberellin-treated fruit also resulted in lower carotenoid concentration after full color development, resulting in paler colored fruit (Lewis and Coggins, 1964; Rasmussen, 1973).

Prohexadione-calcium [ProCa; BAS-125W (3-oxido-4propionyl-5-oxo-3-cyclohexenecarboxylate)] sold as Regalis $\AA$ and Apogee $\AA$ and developed by BASF (Limburgerhof, Germany) is used on pome fruit trees (Malus and Pyrus spp.) to reduce and control vegetative growth (Miller, 2002). Prohexadione-calcium acts primarily as a gibberellin-biosynthesis inhibitor, especially $3 \beta$-hydroxylation of $\mathrm{GA}_{20}$ to $\mathrm{GA}_{1}$ (Nakayama et al., 1992; Rademacher, 2001). Costa et al. (2001) demonstrated that repeated applications of $100 \mathrm{mg} \cdot \mathrm{L}^{-1}$ ProCa significantly reduced shoot growth and increased fruit size in pears ( $P$. communis L.).

In contrast to the affects of gibberellinbiosynthesis inhibitors on vegetative growth, their effects on rind color enhancement of fruit of Citrus spp. have not been studied extensively. Monselise et al. (1976) reported that paclobutrazol contributed to the acceleration of chlorophyll degradation of sweet orange. Gilfillan and Lowe (1985) demonstrated that paclobutrazol increased 'Satsuma' mandarin (C. unshiu Marc.) rind color by one to two color rating units when applied after physiological fruit drop (in November) at $1 \mathrm{~g} \cdot \mathrm{L}^{-1}$ as well as in summer (January and February) and suggest that paclobutrazol suppressed the early summer growth flush (November to December), which may be more important for rind color development than the late summer flush (January to February). Monselise (1986)

\footnotetext{
Received for publication 31 Aug. 2009. Accepted for publication 25 Nov. 2009.

This study was made possible by partial funding from Citrus Growers' Association of Southern Africa, Citrus Research International, the National Research Foundation (under Grant number NRF 2046844), and Du Roi Nursery.

We thank Willem van Kerwel for technical assistance and grower cooperators for graciously providing the experimental sites and fruit for this study.

${ }^{1}$ Present address: GCM Variedades Vegetales AIE, Valencia, Spain.

${ }^{2}$ To whom reprint requests should be addressed; e-mail ghbarry@gmail.com.
}

mentioned that paclobutrazol caused a more rapid change of rind color in 'Topaz' tangor (C. reticulata Blanco $\times C$. paradisi Macf.), an Israeli selection of 'Ortanique' tangor. Preliminary results by Barry and Van Wyk (2004) showed that when ProCa was applied 2 weeks before anticipated harvest at 100 $\mathrm{mg} \cdot \mathrm{L}^{-1}$ to 'Navelina Navel' orange, rind color was improved as a result of chlorophyll degradation and carotenoid biosynthesis. No other reports in the literature on the possible affect of gibberellin-biosynthesis inhibitors on rind color enhancement of fruit of Citrus spp. were found.

The principal objective of this study was to determine whether a recently developed gibberellin-biosynthesis inhibitor would improve the rind color of citrus fruit. The concentration and timing of ProCa applications required to stimulate chlorophyll degradation and/or carotenoid synthesis were tested on several early-maturing citrus cultivars treated with different concentrations of ProCa at various stages of fruit development.

\section{Materials and Methods}

\section{Sites, plant material, treatments, and experimental design}

Three citrus cultivars at different locations in the Western Cape province, South Africa, were used during the 2005 and 2006 seasons (Table 1). Different sites and plant materials were used to test the treatments on different cultivars and under different climatic conditions and to minimize the possibility of experimental loss. In all cases, mature citrus trees between 8 and 12 years of age were used, i.e., the trees were in their fifth to eighth cropping season. Healthy trees with uniform crop load and tree size were selected, and cultural practices were the same for all trees within a given site, e.g., rootstock, spacing, pruning, nutrition, and irrigation. Differences among sites in soil type and microclimate are not described because comparisons in this study are only made within sites and not between sites and species.

Prohexadione-calcium (Regalis ${ }^{\circledR}$ containing $10 \%$ ProCa) was applied as a mediumcover spray to just before runoff with a handheld spray gun by targeting the outer leaf canopy and adjacent fruit. Application rates were 200 and $400 \mathrm{mg} \cdot \mathrm{L}^{-1}$ ProCa, and, depending on tree size, 5 to $8 \mathrm{~L}$ of ProCa solution was applied per tree. In the 2005 season, ProCa was applied up to five times over a period of almost 5 months depending on harvest date. In the 2006 season, ProCa was applied as a double application either as an early or late treatment aimed to coincide with the late summer or preharvest periods, respectively. Untreated trees between treated trees served as a buffer between treatments. The different times of application are summarized in Table 1. In addition to the foliar spray applications, individual 'Eureka' lemon fruit and fruit plus leaves were dipped on 4 May 2005 in 200 and $400 \mathrm{mg} \cdot \mathrm{L}^{-1}$ ProCa solutions because the bulk of the lemon crop had been commercially harvested before sampling. All ProCa treatments were compared with an untreated, control treatment.

The experimental design was a randomized complete block design consisting of eight single-tree replicates.

\section{Fruit sampling}

To limit unwanted, natural within-tree variation in rind color, fruit were sampled from specific canopy positions at a height of 1.5 to $2.0 \mathrm{~m}$. In the 2005 season, fruit were sampled from the outer, eastern side of trees and from both the outer, eastern and western sides of the trees in the 2006 season. For brevity, only data for fruit sampled from the eastern side of the trees are presented in this report. In all cases, the fruit were harvested when physiologically mature as determined by standard internal fruit quality tests.

During the 2005 season, 30 'Nules Clementine' fruit per tree were sampled from each replicate, of which 10 fruit were used for immediate analysis and the remaining 20 fruit underwent ethylene degreening. After ethylene degreening, 10 fruit were analyzed and the remaining 10 fruit were stored at $7.5^{\circ} \mathrm{C}$ for 2 weeks followed by 1 week at $18^{\circ} \mathrm{C}$ to simulate early-season commercial shipping conditions. For 'Navelina Navel' orange, 20 fruit were sampled per replicate, of which 10 fruit were used for immediate analysis and the remaining 10 fruit were degreened and then analyzed. For 'Eureka' lemon, only the dipped fruit were sampled because the bulk of the crop had been commercially harvested before sampling. Ten fruit per replicate were sampled for immediate analysis.

During the 2006 season, 30 fruit were sampled from each replicate from 'Nules Clementine' mandarin and 'Navelina Navel' orange trees. Ten fruit were used for immediate analysis and the remaining 20 fruit were degreened. After ethylene degreening, 10 fruit were analyzed and the remaining 10 fruit were stored at $4.5{ }^{\circ} \mathrm{C}$ for 2 weeks followed by 1 week at $18{ }^{\circ} \mathrm{C}$. For 'Eureka' lemon, 20 fruit were sampled at a height of 1.0 to $1.5 \mathrm{~m}$. Ten fruit were used for immediate analysis and 10 fruit were degreened and then analyzed.

Ethylene degreening was conducted at $23{ }^{\circ} \mathrm{C}$ with a relative humidity of $95 \%$, an ethylene concentration of $2 \mathrm{mg} \cdot \mathrm{L}^{-1}$, and a carbon dioxide $\left(\mathrm{CO}_{2}\right)$ concentration less than $0.3 \%$ according to standard commercial practices (Krajewski and Pittaway, 2002). 'Nules Clementine' mandarin fruit were subjected to an ethylene degreening time of $48 \mathrm{~h}$, whereas 'Navelina Navel' orange and 'Eureka' lemon were degreened for $72 \mathrm{~h}$. The fruit were drenched with $125 \mathrm{mg} \cdot \mathrm{L}^{-1}$ 2,4-dichlorophenoxyacetic acid, $500 \mathrm{mg} \cdot \mathrm{L}^{-1}$ Tecto ${ }^{\circledR}$ (thiabendazole), and $120 \mathrm{mg} \cdot \mathrm{L}^{-1} \quad$ Sporekill $^{\mathrm{TM}}$ (didecyldimethylammonium chloride) and waxed with a polyethylene wax before undergoing simulated shipping conditions.

\section{Data collection}

Rind color. Fruit were color-rated using the "CRI colour charts, set no. 34, 36 and 37, 2004" for oranges, soft citrus (syn. mandarins), 
Table 1. Summary of plant material, site details, application dates, and harvest dates of experiments to determine the concentration and timing of prohexadionecalcium (ProCa) applications required to improve the rind color of citrus fruit. ${ }^{\mathrm{z}}$

\begin{tabular}{|c|c|c|c|}
\hline Plant material & Site details & Application dates or timing & Harvest date \\
\hline \multicolumn{4}{|c|}{2005 season } \\
\hline $\begin{array}{l}\text { 'Nules Clementine' } \\
\text { mandarin }\end{array}$ & $\begin{array}{l}\text { Welgevallen Experimental Farm (Stellenbosch); } \\
\text { long. } 33^{\circ} 57^{\prime} \mathrm{S} \text {, lat. } 18^{\circ} 53^{\prime} \mathrm{E} ; 120 \mathrm{~m} \text { alt. }\end{array}$ & $\begin{array}{l}8 \text { and } 28 \text { Dec. } 2004,1 \text { Feb. } 2005 \text {, and } 4 \text { (8 Apr. 2005) } \\
\text { and } 2 \text { (28 Apr. 2005) weeks before anticipated harvest }\end{array}$ & 13 May 2005 \\
\hline $\begin{array}{l}\text { 'Navelina Navel' } \\
\text { orange }\end{array}$ & $\begin{array}{l}\text { Hexrivier Estates (Citrusdal); } \\
\text { long. } 32^{\circ} 28^{\prime} \mathrm{S} \text {, lat. } 18^{\circ} 58^{\prime} \mathrm{E} ; 180 \mathrm{~m} \text { alt. }\end{array}$ & $\begin{array}{l}4 \text { (7 Apr. 2005) and } 2 \text { (21 Apr. 2005) } \\
\text { weeks before anticipated harvest }\end{array}$ & 5 May 2005 \\
\hline 'Eureka' lemon & $\begin{array}{l}\text { Jericho Farm (Gt. Drakenstein); } \\
\text { long. } 33^{\circ} 52^{\prime} \mathrm{S} \text {, lat. } 19^{\circ} 01^{\prime} \mathrm{E} ; 160 \mathrm{~m} \text { alt. }\end{array}$ & $\begin{array}{l}8 \text { and } 28 \text { Dec. } 2004,1 \text { Feb. } 2005,4 \text { (8 Apr. 2005) } \\
\text { and } 2 \text { (28 Apr. 2005) weeks before anticipated harvest }\end{array}$ & 25 May 2005 \\
\hline \multicolumn{4}{|c|}{2006 season } \\
\hline $\begin{array}{l}\text { 'Nules Clementine' } \\
\text { mandarin }\end{array}$ & $\begin{array}{l}\text { Diamant Farm (Paarl); } \\
\text { long. } 33^{\circ} 46^{\prime} \mathrm{S} \text {, lat. } 18^{\circ} 55^{\prime} \mathrm{E} ; 140 \mathrm{~m} \text { alt. }\end{array}$ & $\begin{array}{l}\text { Early: } 19 \text { Dec. } 2005 \text { and } 17 \text { Jan. } 2006 \\
\text { Late: } 6 \text { (28 Mar. 2006) and } 3 \text { (12 Apr. 2006) } \\
\quad \text { weeks before anticipated harvest }\end{array}$ & 8 May 2006 \\
\hline $\begin{array}{l}\text { 'Navelina Navel' } \\
\text { orange }\end{array}$ & $\begin{array}{l}\text { Hexrivier Estates (Citrusdal); } \\
\text { long. } 32^{\circ} 28^{\prime} \mathrm{S} \text {, lat. } 18^{\circ} 58^{\prime} \mathrm{E} ; 180 \mathrm{~m} \text { alt. }\end{array}$ & $\begin{array}{l}\text { Early: } 14 \text { Dec. } 2005 \text { and } 16 \text { Jan. } 2006 \\
\text { Late: } 6 \text { ( } 8 \text { Mar. 2006) and } 3 \text { (23 Mar. 2006) } \\
\text { weeks before anticipated harvest }\end{array}$ & 3 May 2006 \\
\hline 'Eureka' lemon & $\begin{array}{l}\text { Jericho Farm (Gt. Drakenstein); } \\
\text { long. } 33^{\circ} 52^{\prime} \mathrm{S} \text {, lat. } 19^{\circ} 01^{\prime} \mathrm{E} ; 160 \mathrm{~m} \text { alt. }\end{array}$ & $\begin{array}{l}\text { Early: } 15 \text { Dec. } 2005 \text { and } 17 \text { Jan. } 2006 \\
\text { Late: } 6 \text { (23 Mar. 2006) and } 3 \text { (11 Apr. 2006) } \\
\text { weeks before anticipated harvest }\end{array}$ & 12 May 2006 \\
\hline
\end{tabular}

${ }^{\mathrm{z}}$ On each application date, ProCa was applied at 200 and $400 \mathrm{mg} \cdot \mathrm{L}^{-1}$.

and lemons, respectively (CRI, 2004) comprising a set of color prints made up of a series of photographs of citrus fruit ranging in degree of color development from dark intense green (T8) to fruit at "color break" (T7) (where the chlorophyll has started to break down to reveal the underlying orange color) to brightly colored orange fruit without any visible green (T1) (CRI, 2004). To account for the natural variation in rind color typically perceived on different sides of individual fruit, rind color was also objectively quantified on both the "vivid" (orange) and "dull" (green) sides of fruit using a Minolta chromometer (Model CR400; Minolta Co. Ltd., Tokyo, Japan).

Rind pigments. Rind samples were prepared for pigment analysis by carefully cutting the flavedo from the fruit. The removal of the flavedo was done either with a potato peeler ('Nules Clementine' mandarin) or with a citrus rind zester ('Navelina Navel' orange and 'Eureka' lemon) during the 2005 season. During the 2006 season, only a citrus rind zester was used. Composite rind samples were made by collecting the flavedo from all 10 fruit per replicate, which was immediately immersed in liquid $\mathrm{N}$ and stored at $-80{ }^{\circ} \mathrm{C}$ until completely frozen, whereafter the samples were freeze-dried at $-56{ }^{\circ} \mathrm{C}$ for $4 \mathrm{~d}$ until all moisture was removed from the sample. The dry sample was then milled (A10 Kika Labortechnic; Kika Werke, GMBH \& Co., Staufen, Germany) and sieved through a 500$\mu \mathrm{m}$ sieve to form a homogenous powder. Samples were then stored in polyethylene vials at $-80^{\circ} \mathrm{C}$ until analyzed. All preparation activities were carried out under low light conditions by covering the test tubes with aluminum foil to limit the degradation of carotenoids and chlorophyll.

From the freeze-dried rind sample, a $0.1-\mathrm{g}$ subsample was added to $10 \mathrm{~mL} 96 \%(\mathrm{v} / \mathrm{v})$ aqueous ethanol solvent containing $0.1 \mathrm{~g} \cdot \mathrm{L}^{-1}$ butylated hydroxytoluene and $0.2 \mathrm{~g} \cdot \mathrm{L}^{-1}$ diethyldithiocarbamate, both of which are antioxidants to prevent carotenoid degradation. The sample was then vortexed twice for $1 \mathrm{~min}$ each, whereafter it was stored for $1.5 \mathrm{~h}$ at $4{ }^{\circ} \mathrm{C}$ to allow the pigments to extract into the solvent. After pigment extraction, the extract was poured through ashless filter paper (Schleicher \& Schuell, Dassel, Germany) to remove rind particles. The filtrate was poured into plastic cuvettes, placed into a spectrophotometer [Cary 50 conc ultraviolet-visible spectrophotometer; Varian Australia (Pty) Ltd., Mulgrave, Victoria, Australia], zeroed with an ethanol/antioxidant solvent, and absorbance was measured at 470, 649, and 664 $\mathrm{nm}$. Absorbance values were used to determine chlorophyll $a$, chlorophyll $b$, total chlorophyll, and total carotenoid concentrations in $\mu \mathrm{g} \cdot \mathrm{g}^{-1}$ dry weight using the Lichtenthaler equations (Lichtenthaler, 1987).

\section{Statistical analysis}

Data were analyzed by analysis of variance using the general linear model procedure of Statistical Analysis Systems (Version 9.1; SAS Inc., Cary, NC), and Fisher's least significant difference was used to indicate any significant differences among treatment means.

\section{Results}

'Nules Clementine' mandarin. In the 2005 season, the $400 \mathrm{mg} \cdot \mathrm{L}^{-1}$ ProCa treatment significantly improved rind color rating of 'Nules Clementine' mandarin directly after harvest by 0.9 color rating units compared with the untreated control treatment (Table 2). The $400 \mathrm{mg} \cdot \mathrm{L}^{-1}$ ProCa treatment reduced relative greenness (as evidenced by the significantly lower hue angle) and resulted in fruit appearing brighter (higher lightness) and more intensely colored (higher chroma) after harvest. The perceived improvement in rind color was the result of lower chlorophyll concentration $(P=0.0639)$ (by $\approx 57 \%$ ), resulting in a higher carotenoid-to-chlorophyll ratio $(P=0.0860)$. These differences in rind color variables were smaller after ethylene degreening, but rind color was still significantly improved by the $400 \mathrm{mg} \cdot \mathrm{L}^{-1}$ ProCa treatment (data not shown). After cold storage, however, no significant differences in rind color were observed among treatments (data not shown).
In the 2006 season, rind color rating of 'Nules Clementine' mandarin directly after harvest was significantly improved by the late $400 \mathrm{mg} \cdot \mathrm{L}^{-1}$ ProCa treatment by 0.6 color rating units compared with the untreated control treatment (Table 2). Relative greenness of the rind was reduced by the late 400 $\mathrm{mg} \cdot \mathrm{L}^{-1}$ ProCa treatment (as evidenced by the lower hue angle). Fruit were brighter (higher lightness) and more intensely colored (higher chroma) on the dull side of fruit. The improvement in rind color for the late 400 $\mathrm{mg} \cdot \mathrm{L}^{-1}$ ProCa treatment was the result of significantly higher carotenoid concentrations (by $\approx 25 \%$ ), resulting in a marginally higher carotenoid-to-chlorophyll ratio $(P=$ $0.0645)$. Ethylene degreening improved rind color of all treatments to such an extent that no significant differences in hue angle were observed among treatments after degreening and after cold storage (data not shown).

'Navelina Navel' orange. In the 2005 season, rind color rating of 'Navelina Navel' orange directly after harvest was significantly improved by 1.3 color rating units by the 400 $\mathrm{mg} \cdot \mathrm{L}^{-1}$ ProCa treatment compared with the untreated control treatment (Table 3). Relative greenness of fruit was reduced (as evidenced by the significantly lower hue angle), and fruit were brighter (higher lightness) and more intensely colored (higher chroma) for the $400 \mathrm{mg} \cdot \mathrm{L}^{-1}$ ProCa treatment. The perceived improvement in rind color was the result of to significantly higher carotenoid concentration (by $\approx 15 \%$ ) and significantly lower chlorophyll concentration (by $\approx 41 \%$ ), resulting in a significantly higher carotenoid-to-chlorophyll ratio. However, the differences in rind color variables among treatments were smaller after ethylene degreening (data not shown).

In the 2006 season, rind color rating of 'Navelina Navel' orange directly after harvest was significantly improved by the late $400 \mathrm{mg} \cdot \mathrm{L}^{-1}$ ProCa treatment by 0.2 color rating units compared with the untreated control treatment (Table 3; Fig. 1). Because this was the only treatment that improved rind color, only the data for the late 400 $\mathrm{mg} \cdot \mathrm{L}^{-1}$ ProCa treatment are discussed in 
Table 2. Rind color rating, hue angle, lightness, and chroma measurements were made within 24 h of harvest on the vivid (yellow) and dull (green) sides of 'Nules Clementine' mandarin fruit sampled from the eastern side of trees during the 2005 and 2006 seasons after different prohexadione-calcium (ProCa) treatments. ${ }^{\mathrm{z}}$

\begin{tabular}{|c|c|c|c|c|c|c|c|c|c|c|}
\hline \multirow{2}{*}{$\begin{array}{l}\text { Treatment } \\
\left(\mathrm{mg} \cdot \mathrm{L}^{-1}\right)\end{array}$} & \multirow{2}{*}{$\begin{array}{l}\text { Color } \\
\text { rating }^{\mathrm{y}}\end{array}$} & \multicolumn{2}{|c|}{ Hue angle $\left({ }^{\circ}\right)$} & \multicolumn{2}{|c|}{ Lightness } & \multicolumn{2}{|c|}{ Chroma } & \multirow{2}{*}{$\begin{array}{l}\text { Car. concn } \\
\left(\mu \mathrm{g} \cdot \mathrm{g}^{-1} \mathrm{DW}\right)\end{array}$} & \multirow{2}{*}{$\begin{array}{l}\text { Chl. concn } \\
\left(\mu g \cdot g^{-1} \mathrm{DW}\right)\end{array}$} & \multirow{2}{*}{$\begin{array}{c}\text { Car./Chl. } \\
\text { ratio }\end{array}$} \\
\hline & & Vivid & Dull & Vivid & Dull & Vivid & Dull & & & \\
\hline & & & & & 2005 & & & & & \\
\hline Control & $3.5 \mathrm{a}^{\mathrm{x}}$ & $74.2 \mathrm{a}$ & $83.0 \mathrm{a}$ & $69.9 \mathrm{a}$ & $67.1 \mathrm{~b}$ & $69.9 \mathrm{~b}$ & $64.4 \mathrm{c}$ & $488.8 \mathrm{~b}$ & $130.0 \mathrm{NS}$ & $4.7 \mathrm{NS}$ \\
\hline ProCa 200 & $3.2 \mathrm{a}$ & $70.2 \mathrm{~b}$ & $76.4 \mathrm{~b}$ & $68.6 \mathrm{~b}$ & $67.2 \mathrm{~b}$ & $70.9 \mathrm{ab}$ & $67.7 \mathrm{~b}$ & $595.3 \mathrm{a}$ & 81.0 & 12.2 \\
\hline ProCa 400 & $2.6 \mathrm{~b}$ & $70.3 \mathrm{~b}$ & $75.8 \mathrm{~b}$ & $70.2 \mathrm{a}$ & $69.7 \mathrm{a}$ & $71.4 \mathrm{a}$ & $70.3 \mathrm{a}$ & $503.7 \mathrm{~b}$ & 55.3 & 10.7 \\
\hline \multirow[t]{2}{*}{$P$ value } & 0.0006 & $<0.0001$ & $<0.0001$ & $<0.0001$ & 0.0006 & 0.0456 & $<0.0001$ & 0.0448 & 0.0639 & 0.0860 \\
\hline & & & & & 2006 & & & & & \\
\hline Control & $4.6 \mathrm{a}$ & $83.2 \mathrm{~b}$ & $93.0 \mathrm{a}$ & $67.5 \mathrm{a}$ & $59.8 \mathrm{bc}$ & $64.6 \mathrm{a}$ & $54.7 \mathrm{bc}$ & $461.5 \mathrm{bc}$ & $243.0 \mathrm{~b}$ & $2.19 \mathrm{NS}$ \\
\hline ProCa early 200 & $4.5 \mathrm{a}$ & $84.8 \mathrm{ab}$ & $94.5 \mathrm{a}$ & $66.0 \mathrm{ab}$ & $59.8 \mathrm{bc}$ & $62.8 \mathrm{ab}$ & $53.9 \mathrm{bc}$ & $456.0 \mathrm{bc}$ & $294.0 \mathrm{~b}$ & 1.95 \\
\hline ProCa early 400 & $4.7 \mathrm{a}$ & $86.6 \mathrm{a}$ & $94.1 \mathrm{a}$ & $66.1 \mathrm{ab}$ & $61.1 \mathrm{ab}$ & $63.0 \mathrm{ab}$ & $55.9 \mathrm{~b}$ & $431.5 \mathrm{c}$ & $291.6 \mathrm{~b}$ & 1.61 \\
\hline ProCa late 200 & $4.7 \mathrm{a}$ & $85.9 \mathrm{ab}$ & $95.0 \mathrm{a}$ & $65.0 \mathrm{~b}$ & $58.4 \mathrm{c}$ & $61.2 \mathrm{~b}$ & $52.3 \mathrm{c}$ & $538.0 \mathrm{ab}$ & $403.6 \mathrm{a}$ & 1.41 \\
\hline ProCa late 400 & $4.0 \mathrm{~b}$ & $76.3 \mathrm{c}$ & $84.5 \mathrm{~b}$ & $66.1 \mathrm{ab}$ & $63.0 \mathrm{a}$ & $64.9 \mathrm{a}$ & $59.2 \mathrm{a}$ & $617.1 \mathrm{a}$ & $236.0 \mathrm{~b}$ & 2.95 \\
\hline$P$ value & $<0.0001$ & $<0.0001$ & $<0.0001$ & 0.0329 & 0.0012 & 0.0055 & $<0.0001$ & 0.0093 & 0.0277 & 0.0645 \\
\hline
\end{tabular}

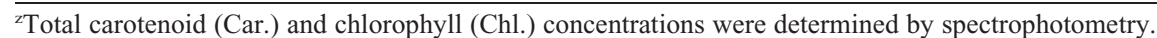

${ }^{\mathrm{y}}$ Rind color rating in which 1 = fully colored fruit and 8 = totally dark green fruit (CRI, 2004; color chart, set no. 36).

${ }^{\mathrm{x}}$ Means within columns followed by a different letter are significantly different $(P \leq 0.05$; NS $=$ nonsignificant).

$\mathrm{DW}=$ dry weight.

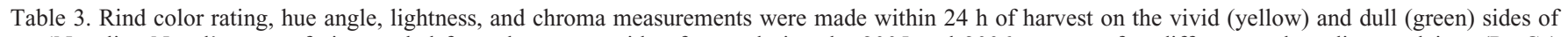
'Navelina Navel' orange fruit sampled from the eastern side of trees during the 2005 and 2006 seasons after different prohexadione-calcium (ProCa) treatments. ${ }^{\mathrm{z}}$

\begin{tabular}{|c|c|c|c|c|c|c|c|c|c|c|}
\hline \multirow{2}{*}{$\begin{array}{l}\text { Treatment } \\
\left(\mathrm{mg} \cdot \mathrm{L}^{-1}\right)\end{array}$} & \multirow{2}{*}{$\begin{array}{l}\text { Color } \\
\text { rating }\end{array}$} & \multicolumn{2}{|c|}{ Hue angle $\left({ }^{\circ}\right)$} & \multicolumn{2}{|c|}{ Lightness } & \multicolumn{2}{|c|}{ Chroma } & \multirow{2}{*}{$\begin{array}{l}\text { Car. concn } \\
\left(\mu \mathrm{g} \cdot \mathrm{g}^{-1} \mathrm{DW}\right)\end{array}$} & \multirow{2}{*}{$\begin{array}{l}\text { Chl. concn } \\
\left(\mu \mathrm{g} \cdot \mathrm{g}^{-1} \mathrm{DW}\right)\end{array}$} & \multirow{2}{*}{$\begin{array}{c}\text { Car./Chl } \\
\text { ratio }\end{array}$} \\
\hline & & Vivid & Dull & Vivid & Dull & Vivid & Dull & & & \\
\hline & & & & & 2005 & & & & & \\
\hline Control & $5.2 \mathrm{a}^{\mathrm{x}}$ & $91.4 \mathrm{a}$ & $104.0 \mathrm{a}$ & $68.4 \mathrm{~b}$ & $56.9 \mathrm{~b}$ & $64.8 \mathrm{c}$ & $52.5 \mathrm{c}$ & $193.9 \mathrm{~b}$ & $211.1 \mathrm{a}$ & $1.1 \mathrm{~b}$ \\
\hline ProCa 200 & $4.4 \mathrm{~b}$ & $87.9 \mathrm{~b}$ & $99.9 \mathrm{~b}$ & $69.6 \mathrm{ab}$ & $58.6 \mathrm{~b}$ & $66.9 \mathrm{~b}$ & $54.9 \mathrm{~b}$ & $210.0 \mathrm{ab}$ & $158.7 \mathrm{ab}$ & $1.5 \mathrm{ab}$ \\
\hline ProCa 400 & $3.9 \mathrm{c}$ & $84.2 \mathrm{c}$ & $96.9 \mathrm{c}$ & $70.0 \mathrm{a}$ & $61.2 \mathrm{a}$ & $69.0 \mathrm{a}$ & $58.2 \mathrm{a}$ & $229.3 \mathrm{a}$ & $124.7 \mathrm{~b}$ & $2.1 \mathrm{a}$ \\
\hline \multirow[t]{2}{*}{$P$ value } & $<0.0001$ & $<0.0001$ & $<0.0001$ & 0.0013 & $<0.0001$ & $<0.0001$ & $<0.0001$ & 0.0462 & 0.0343 & 0.0211 \\
\hline & & & & & 2006 & & & & & \\
\hline Control & $5.0 \mathrm{~b}$ & $99.2 \mathrm{a}$ & $110.5 \mathrm{a}$ & $64.5 \mathrm{~b}$ & $53.5 \mathrm{c}$ & $59.2 \mathrm{c}$ & $47.4 \mathrm{~cd}$ & $263.3 \mathrm{NS}$ & $384.7 \mathrm{ab}$ & $0.71 \mathrm{~b}$ \\
\hline ProCa early 200 & $5.3 \mathrm{a}$ & $100.2 \mathrm{a}$ & $111.6 \mathrm{a}$ & $65.0 \mathrm{~b}$ & $53.5 \mathrm{c}$ & $58.3 \mathrm{c}$ & $46.0 \mathrm{~d}$ & 261.6 & $443.8 \mathrm{a}$ & $0.59 \mathrm{~b}$ \\
\hline ProCa early 400 & $5.1 \mathrm{ab}$ & $99.3 \mathrm{a}$ & $110.1 \mathrm{a}$ & $65.4 \mathrm{~b}$ & $54.7 \mathrm{bc}$ & $59.6 \mathrm{c}$ & $48.1 \mathrm{bc}$ & 258.8 & $409.8 \mathrm{a}$ & $0.65 \mathrm{~b}$ \\
\hline ProCa late 200 & $5.0 \mathrm{bc}$ & $96.6 \mathrm{~b}$ & $108.3 \mathrm{~b}$ & $68.0 \mathrm{a}$ & $56.0 \mathrm{~b}$ & $62.2 \mathrm{~b}$ & $49.7 \mathrm{~b}$ & 262.2 & $402.3 \mathrm{a}$ & $0.67 \mathrm{~b}$ \\
\hline ProCa late 400 & $4.8 \mathrm{c}$ & $92.9 \mathrm{c}$ & $102.4 \mathrm{c}$ & $69.1 \mathrm{a}$ & $59.8 \mathrm{a}$ & $64.1 \mathrm{a}$ & $54.8 \mathrm{a}$ & 255.0 & $302.5 \mathrm{~b}$ & $0.93 \mathrm{a}$ \\
\hline$P$ value & $<0.0001$ & $<0.0001$ & $<0.0001$ & $<0.0001$ & $<0.0001$ & $<0.0001$ & $<0.0001$ & 0.9425 & 0.0252 & 0.0017 \\
\hline
\end{tabular}

${ }^{\mathrm{z}}$ Total carotenoid (Car.) and chlorophyll (Chl.) concentrations were determined by spectrophotometry.

${ }^{\mathrm{y}}$ Rind color rating in which $1=$ fully colored fruit and $8=$ totally dark green fruit (CRI, 2004; color chart, set no. 34).

${ }^{\mathrm{x}}$ Means within columns followed by a different letter are significantly different $(P \leq 0.05$; Ns $=$ nonsignificant $)$.

$\mathrm{DW}=$ dry weight.

detail. The late $400 \mathrm{mg} \cdot \mathrm{L}^{-1}$ ProCa treatment had a significantly lower hue angle, higher lightness and chroma, resulting in lower relative greenness of rinds as well as brighter and more intense-colored fruit (Fig. 1). The perceived rind color improvement was the result of lower chlorophyll concentration (by $\approx 21 \%$ ), resulting in a significantly higher carotenoid-to-chlorophyll ratio. After ethylene degreening and after cold storage, however, rind color of the late $400 \mathrm{mg} \cdot \mathrm{L}^{-1}$ ProCa treatment was not different from that of the control treatment (data not shown).

'Eureka' lemon. In the 2005 season, rind color rating of 'Eureka' lemon fruit was significantly improved (by 0.5 color rating units) by both the 200 and $400 \mathrm{mg} \cdot \mathrm{L}^{-1}$ ProCa fruit dip treatments (Table 4 ) and by 0.4 color rating units by the $400 \mathrm{mg} \cdot \mathrm{L}^{-1}$ ProCa fruit and leaf dip treatment (data not shown) compared with the untreated control treatment. However, colorimeter measurements and pigment concentrations did not differ among treatments.

In the 2006 season, rind color rating of 'Eureka' lemon fruit sampled from the western side of trees was significantly improved by 0.5 color rating units by the early $200 \mathrm{mg} \cdot \mathrm{L}^{-1}$ and both the late 200 and $400 \mathrm{mg} \cdot \mathrm{L}^{-1} \mathrm{ProCa}$ treatments compared with the untreated control treatment (data not shown), but not on the eastern side (Table 4). Colorimeter measurements showed that the late $400 \mathrm{mg} \cdot \mathrm{L}^{-1}$ ProCa treatment significantly improved rind color of fruit borne on both the eastern (Table 4) and western (data not shown) sides of trees, and these data are therefore discussed in detail. The late $400 \mathrm{mg} \cdot \mathrm{L}^{-1}$ ProCa treatment significantly reduced the relative greenness of fruit as evidenced by the lower hue angle. Fruit also appeared brighter (higher lightness) on the western side of trees and were more intensely colored (higher chroma) on both the vivid and dull sides of fruit sampled from both the eastern (Table 4) and western sides of trees. The perceived improvement in rind color was the result of a significant reduction in chlorophyll concentration (by $\approx 38 \%$ ), resulting in a significantly higher carotenoid-to-chlorophyll ratio of fruit sampled from the eastern side of trees. After degreening, however, there were no significant differences in rind color rating among treatments nor in pigment concentration compared with the untreated control treatment (data not shown).

\section{Discussion}

To determine the concentration and timing of prohexadione-calcium (ProCa) applications (a gibberellin-biosynthesis inhibitor with growth retardant activity) required to improve rind color of citrus fruit by stimulating chlorophyll degradation and/or carotenoid synthesis, several early-maturing citrus cultivars were treated with different concentrations of ProCa at various stages of fruit development.

The late $400 \mathrm{mg} \cdot \mathrm{L}^{-1}$ ProCa treatment, applied 6 plus 3 weeks before anticipated harvest, consistently improved rind color on the citrus cultivars tested, namely 'Nules Clementine' mandarin, 'Navelina Navel' orange, and 'Eureka' lemon. However, these effects were more pronounced at harvest, because ethylene degreening and cold-storage stimulated additional chlorophyll degradation. In most cases, ProCa stimulated both chlorophyll degradation and carotenoid biosynthesis. These changes in pigment concentrations resulted in a higher carotenoid-to-chlorophyll ratio and, therefore, improved rind color.

The improvement of rind color after the application of ProCa is supported by previous 

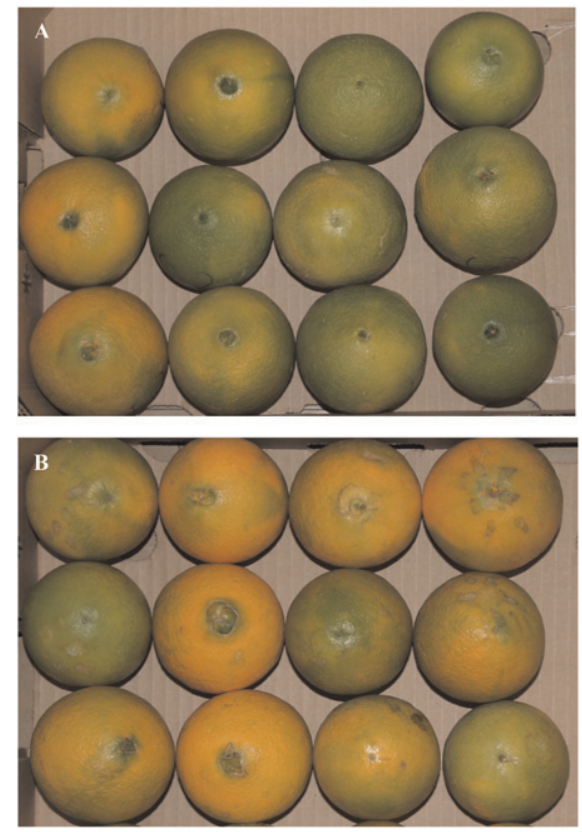

Fig. 1. Photographs of 'Navelina Navel' orange fruit taken after harvest of fruit sampled during the 2006 season from the eastern side of trees to illustrate the effect of ProCa on rind color enhancement. (A) Untreated control; (B) late $400 \mathrm{mg} \cdot \mathrm{L}^{-1}$ ProCa treatment. Note the more intensely colored fruit of the ProCa treatment compared with the untreated control treatment. (To view this figure in color, please view the paper online through the ASHS website: ashs. org.)

work with paclobutrazol, also a gibberellinbiosynthesis inhibitor (Gilfillan and Lowe, 1985; Monselise, 1986; Monselise et al., 1976) and by the preliminary results of Barry and Van Wyk (2004).

Prohexadione-calcium has been shown to reduce vegetative growth in Citrus spp. (Le Roux and Barry, 2010; Stover et al., 2004), similar to the effects of paclobutrazol (Aron et al., 1985; Delgado et al., 1986; Smeirat and Qrunfleh, 1989) and uniconazole (Wheaton, 1989). Therefore, the improvement of rind color of citrus fruit in the current study after the application of a gibberellin-biosynthesis inhibitor $\left(400 \mathrm{mg} \cdot \mathrm{L}^{-1}\right.$ ProCa applied 6 plus 3 weeks before harvest) supports the hypothesis that there may be an inverse relationship between vegetative vigor and rind color development of citrus fruit, although vegetative vigor was not measured in the current study and supports Goldschmidt's (1988) hypothesis that factors contributing to invigorating growing conditions are antagonistic to optimal rind color development.

In a separate but related experiment, Le Roux and Barry (2010) showed that ProCa reduced vegetative growth of 'Eureka' lemon when applied at 400 to $800 \mathrm{mg} \cdot \mathrm{L}^{-1}$ a.i. Costa et al. (2001) demonstrated that repeated applications of $100 \mathrm{mg} \cdot \mathrm{L}^{-1}$ ProCa significantly reduced shoot growth in pears $(P$. communis L.), and ProCa is commercially used on pome fruit trees (Malus and Pyrus spp.) to reduce and control vegetative growth (Miller, 2002).

The mechanism by which ProCa affected chlorophyll degradation and carotenoid synthesis was not investigated in this study. Gilfillan et al. (1974) and Goldschmidt (1988) showed that $\mathrm{GA}_{3}$ application and high gibberellin levels in fruit during maturation resulted in unacceptably green fruit at harvest resulting from delayed chloroplast to chromoplast transformation. Gibberellin-treated fruit also resulted in lower carotenoid concentration after full color development, resulting in paler colored fruit (Lewis and Coggins, 1964; Rasmussen, 1973). Therefore, because ProCa is a gibberellin-biosynthesis inhibitor, it is speculated that the increased chlorophyll degradation and carotenoid synthesis measured in this study is coupled to a reduction in the "gibberellin load" in the aerial portion of the citrus tree and that the relative abundance of gibberellins is thought to inhibit chlorophyll degradation and carotenoid synthesis.

In contrast to Gilfillan and Lowe (1985) who applied paclobutrazol after physiological fruit drop (in November) and achieved a better color response than when applied during the summer (January and February), our results showed that the ProCa treatment applied 6 plus 3 weeks before anticipated harvest was more effective and gave a more consistent response than when applied during summer (December and January). Whereas Gilfillan and Lowe's (1985) data suggest that the suppression of the early summer growth flush (November to December) may be more important for rind color development than the late summer flush (January to February), in the current experiment, the early application of ProCa did not affect chlorophyll or carotenoid levels. Although it may be possible to reduce chlorophyll levels after a late spring/ early summer application of a growth retardant (Gilfillan and Lowe, 1985), this timing would likely be too early to elicit an increase in carotenoid synthesis because carotenoid biosynthesis increases only at or shortly after "color break" (Eilati et al., 1969; Gross, 1981; Oberholster, 2001). The decrease in chlorophyll and increase in carotenoid concentrations after the preharvest applications of ProCa supports the notion that the application timing of a growth retardant should occur sufficiently close to "color break" to have an effect on the physiological changes taking place during Stage III of citrus fruit development to elicit the desired increase in the synthesis of carotenoids.

Based on preliminary research to determine the concentration at which ProCa affects vegetative growth (Le Roux and Barry, 2010) and rind color (Barry and Van Wyk, 2004) of Citrus spp., the effect of ProCa on rind color enhancement was tested at two application rates, namely 200 and $400 \mathrm{mg} \cdot \mathrm{L}^{-1}$ a.i. From the results in this experiment, the higher concentration, $400 \mathrm{mg} \cdot \mathrm{L}^{-1} \mathrm{ProCa}$, had a more consistent effect on chlorophyll degradation and carotenoid synthesis than the lower rate. Nevertheless, further optimization of the application rate is required to improve the cost-to-benefit ratio if $\mathrm{ProCa}$ is to be commercially used to improve citrus rind color. In addition, suitable alternative gibberellin-biosynthesis inhibitors, e.g., uniconazole, should also be screened for their possible effect on rind color enhancement.

Because rind color is an important cosmetic preference of consumers when purchasing citrus fruit, these results also have significant practical benefits. For example, citrus growers may be able to harvest fruit

Table 4. Rind color rating, hue angle, lightness, and chroma measurements were made within $24 \mathrm{~h}$ of harvest on the vivid (yellow) and dull (green) sides of 'Eureka' lemon fruit sampled from the eastern side of trees during the 2005 and 2006 seasons after different prohexadione-calcium (ProCa) treatments. ${ }^{2}$

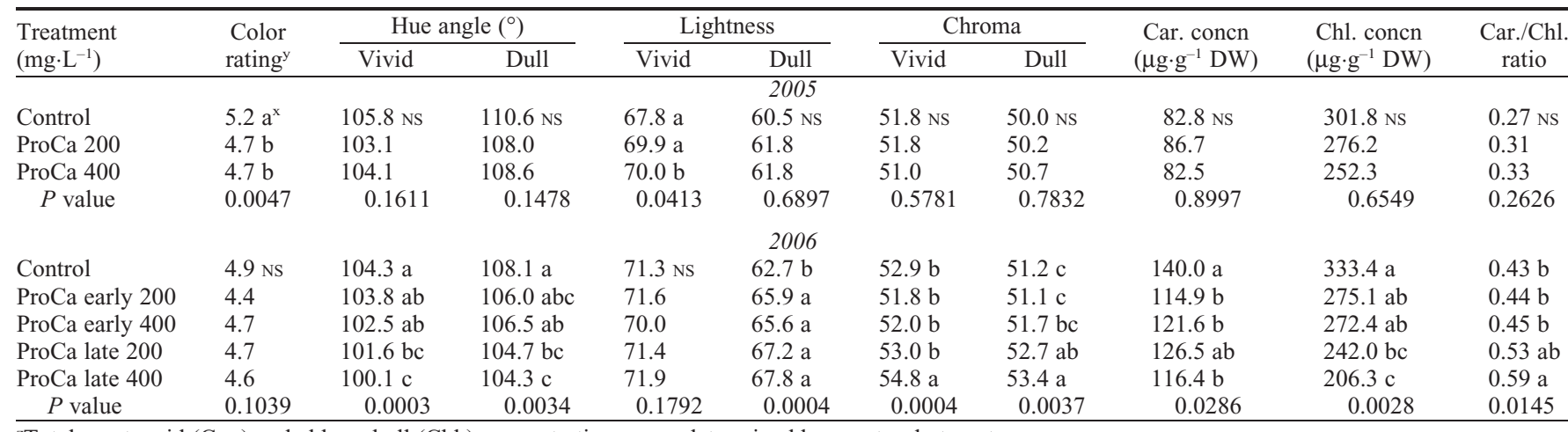

${ }^{\mathrm{z}}$ Total carotenoid (Car.) and chlorophyll (Chl.) concentrations were determined by spectrophotometry.

${ }^{\mathrm{y}}$ Rind color rating in which $1=$ fully colored fruit and $8=$ totally dark green fruit (CRI, 2004; color chart, set no. 37).

${ }^{\mathrm{x}}$ Means within columns followed by a different letter are significantly different $(P \leq 0.05$; Ns $=$ nonsignificant $)$.

$\mathrm{DW}=$ dry weight. 
that have a more intense orange color as a result of the greater carotenoid-to-chlorophyll ratio or they may be able to harvest their fruit earlier, providing that internal quality factors meet the requisite quality standards.

Of the major factors affecting rind color, the effects of growth retardants and the indirect effects of moderating vegetative vigor on rind color development have not previously been studied in depth. This study highlights the important inverse relationship between vegetative vigor and rind color development of citrus fruit and provides a novel approach to manipulate chlorophyll degradation and carotenoid synthesis in citrus fruit. Therefore, by moderating vegetative vigor through the use of growth retardants, chlorophyll degradation and/or carotenoid synthesis can be enhanced, thereby improving rind color of citrus fruit.

\section{Literature Cited}

Aron, Y., S.P. Monselise, R. Goren, and J. Costo. 1985. Chemical control of vegetative growth in citrus trees by paclobutrazol. HortScience 20:96-98.

Barry, G.H. and A.A. Van Wyk. 2004. Novel approaches to rind colour enhancement of citrus. Proc. Int. Soc. Citricult. 3:1076-1079.

Camara, B. and J. Brangeon. 1981. Carotenoid metabolism during chloroplast to chromoplast transformation in Capsicum annuum fruit. Planta 151:359-364.

Coggins C.W., Jr. and L.N. Lewis. 1962. Regreening of Valencia orange as influenced by potassium gibberellate. Plant Physiol. 37:625627.

Costa, G., C. Andreotti, F. Bucchi, E. Sabatini, C. Bazzi, and S. Malaguti. 2001. Prohexadione-Ca (Apogee $\left.{ }^{\circledR}\right)$ : Growth regulation and reduced fire blight incidence in pear. HortScience 36: 931-933.

CRI. 2004. Colour-oranges, soft citrus and lemons Sets No. 34, 36 and 37. Colour prints for blemish standards. Citrus Research International, Nelspruit, South Africa.

Delgado, R., R. Casamayor, J.L. Rodriguez, P. Cruz, and R. Fajardo. 1986. Paclobutrazol effects on oranges under tropical conditions. Acta Hort. 179:537-544.

Eilati, S.K., S.P. Monselise, and P. Budowski. 1969. Seasonal development of external color and carotenoid content in the peel of ripening 'Shamouti' oranges. J. Amer. Soc. Hort. Sci. 94:346-348.

El-Zeftawi, B.M. 1978. Chemical and temperature control of rind pigment of citrus fruits. Proc. Int. Soc. Citricult. p. 33-36.

El-Zeftawi, B.M. and R.G. Garrett. 1978. Plastid ultrastructure in relation to rind pigments and re-greening of Valencia oranges. Proc. Int. Soc. Citricult. p. 37-40.

Garcia-Luis, A., M. Agusti, V. Almela, E. Romero, and J.L. Guardiola. 1985. Effects of gibberellic acid on ripening and peel puffing in Satsuma mandarin. Scientia Hort. 27:75-86.
Garcia-Luis, A., F. Fornes, and J.L. Guardiola. 1986. Effect of gibberellin $A_{3}$ and cytokinins on natural and post-harvest, ethylene-induced pigmentation of Satsuma mandarin peel. Physiol. Plant. 68:271-274.

Gilfillan, I.M. and S.J. Lowe. 1985. Fruit colour improvement in Satsumas with paclobutrazol and ethephon-Preliminary studies. Citrus J. 5:4-8.

Gilfillan, I.M., J.K.A. Stevenson, and W. Koekemoer. 1974. Gibberellic acid reduces creasing in lateseason navels. Citrus Subtrop. Fruit J. 482:4-5.

Goldschmidt, E.E. 1988. Regulatory aspects of chloro-chromoplast interconvensions in senescing Citrus fruit peel. Isr. J. Bot. 47:123-130.

Gross, J. 1981. Pigment changes in the flavedo of Dancy tangerine (Citrus reticulata) during ripening. Z. pflanzenphysiol. Bd. 104(suppl): 451-457.

Jackson, L.K. and F.S. Davies. 1999. Citrus growing in Florida. 4th Ed. University Press of Florida, Gainesville, FL. p. 263-264.

Koo, R.C.J. 1988. Fertilization and irrigation effects on fruit quality, p. 35-42. In: Ferguson, J.J. and W.F. Wardowski (eds.). Factors affecting fruit quality. Proc., Citrus short course. Citrus Research and Education Centre, Lake Alfred, FL.

Krajewski, A. 1997. Guidelines for the improvement of fruit colour in citrus, p. 1-25. In: von Broembsen, L.A. (ed.). Outspan International, Centurion, South Africa.

Krajewski, A.J. and T.M. Pittaway. 2002. The "correct manner of treatment," p. 2. In: Barry, G.H. (ed.). Common defects associated with degreening of citrus. Citrus Research International, Nelspruit, South Africa.

Le Roux, S. and G.H. Barry. 2010. Vegetative growth responses of Citrus nursery trees to various growth retardants. HortTechnology 20:197-201.

Lewis, L.N. and C.W. Coggins, Jr. 1964. The inhibition of carotenoid accumulation in navel oranges by gibberellin $A_{3}$, as measured by thin layer chromatography. Plant Cell Physiol. 5:457-463.

Lichtenthaler, H.K. 1987. Chlorophylls and carotenoids: Pigments of photosynthetic biomembranes. Methods Enzymol. 148:350-382.

Mayfield, S.P. and A. Huff. 1986. Accumulation of chlorophyll, chloroplastic proteins, and thylakoid membranes during reversion of chromoplasts to chloroplasts in Citrus sinensis epicarp. Plant Physiol. 81:31-35.

Miller, S.S. 2002. Prohexadione-calcium controls vegetative shoot growth in apple. J. Tree Fruit Production 3:11-28.

Monselise, S.P. 1986. Growth retardation of shoot and peel growth in citrus by paclobutrazol. Acta Hort. 179:529-535.

Monselise, S.P., M. Weiser, N. Shafir, R. Goren, and E.E. Goldschmidt. 1976. Creasing of orange peel-Physiology and control. J. Hort. Sci. 51:341-351.

Mudzunga, M.J. 2000. Enhancement of vegetative growth in young citrus plantings. MSc Agric. thesis, Univ. Stellenbosch, Stellenbosch, South Africa.

Nakayama, I., M. Kobayashi, Y. Kamiya, H. Abe, and A. Sakurai. 1992. Effects of plant-growth regulator, prohexadione-calcium (BX-112), on the endogenous levels of gibberellins in rice. Plant Cell Physiol. 33:59-62.

Oberholster, R. 2001. The Biochemical basis of colour as an aesthetic quality in Citrus sinensis. MSc thesis, University of Natal, Pietermaritzburg, South Africa.

Peng, Y.H. and E. Rabe. 1996. Improvement of internal quality in 'Mihowase' Satsuma by summer girdling and regulated deficit irrigation. Proc. Int. Soc. Citricult. 2:725-729.

Rabe, E. and L.A. Von Broembsen. 1995. Rootstock choice, p. 1-23. In: Netterville, R.M. (ed.). Production practices for export citrus. Outspan International, Centurion, South Africa.

Rademacher, W. 2001. BAS 12510 W("Regalis")-General information and biological profile. BASF Global PGR Research and Development, Limburgerhof, Germany.

Rasmussen, G.K. 1973. The effect of growth regulators on degreening and regreening of Citrus fruit. Acta Hort. 34:473-479.

Reitz, H.J. and R.C.J. Koo. 1960. Effect of nitrogen and potassium fertilisation on yield, fruit quality, and leaf analysis of Valencia orange. Proc. Am. Soc. Hort. Sci. 75:244-252.

Saidha, T., E.E. Goldschmidt, and S.P. Monselise. 1983. Endogenous growth regulators in tracheal sap of citrus. HortScience 18:231232.

Salisbury, F.B. and C.W. Ross. 1992. Hormones and growth regulators: auxins and gibberellins, p. 357-381. In: Carey, J.C. (ed.). Plant physiology. Wadsworth Publishing Company, Belmont, CA.

Saunt, J. 2000. Citrus varieties of the world. 2nd Ed. Sinclair Intl. Ltd., Norwich, UK.

Sites, J.W. and H.J. Reitz. 1949. The variation in individual Valencia orange from different locations on the tree as a guide to sampling methods and spot-picking for quality. I. Soluble solids in the juice. Proc. Amer. Soc. Hort. Sci. $54: 1-9$.

Smeirat, N. and M. Qrunfleh. 1989. Effect of paclobutrazol on vegetative and reproductive growth of 'Lisbon' lemon. Acta Hort. 239:261264.

Spiegel-Roy, P. and E.E. Goldschmidt. 1996. Fruit development and maturation, p. 92-107. In: Spiegel-Roy, O.P. and E.E. Goldschmidt (eds.). Biology of horticultural crops. Cambridge Univ. Press, Cambridge, UK.

Stover, E.W., S.M. Ciliento, and M.E. Myers 2004. Response of six citrus genotypes to prohexadione-Ca. Plant Growth Regulat. Soc. Amer. 32:86

Syvertsen, J.P. 1981. Hydraulic conductivity of four commercial citrus rootstocks. J. Amer. Soc. Hort. Sci. 106:378-381.

Thomson, W.W. 1966. Ultrastructural development of chromoplasts in Valencia oranges. Bot. Gaz. 127:133-139.

Wheaton, T.A. 1989. Triazole bioregulators reduce internode length and increase branch angle of citrus. Acta Hort. 239:277-280.

Young, L.B. and L.C. Erickson. 1961. Influences of temperature on color change in Valencia oranges. Proc. Amer. Soc. Hort. Sci. 78:197200 . 